\title{
MODELLING THE SPECTRAL CHARACTERISTICS OF THE CIRCULATORY SYSTEM OF ATHLETES-SKIERS
}

\author{
V. I. Zalyapin ${ }^{1}$, zaliapinvi@susu.ru, \\ A. P. Isaev ${ }^{1}$, isaevap@susu.ru, \\ A. S. Bakhareva ${ }^{1}$, bakharevaas@susu.ru, \\ A. S. Aminova ${ }^{1}$, aminovaas@susu.ru \\ ${ }^{1}$ South Ural State University, Chelyabinsk, Russian Federation
}

\begin{abstract}
The circulatory system is an universal indicator of adaptation. In the Central hemodynamics, oscillations occur on the basis of changes in the cycle of each heartbeat. Variability of these indicators is caused by interrelations of functioning of blood circulation and dynamic reactions of regulatory systems. Heart rate oscillations change hemodynamics, modelling the pulsation of blood flow, which in comparison with the rigid rhythm increases energy consumption. The basis for the quantitative analysis of the level of adaptation of athletes to physical activity was a simulation model of the spectral structure of the studied physiological parameters of athletes. It turns out that the spectral structure of physiological parameters of athletes can be adequately described by the Dirichlet distribution. In this case, each individual indicator is characterized by its own parameters of this distribution, which are determined by the available experimental data. We construct a stochastic model of spectral parameters of morphofunctional indices of sportsmen, which allows to establish a connection between Dirichlet distribution parameters, morphofunctional indices and qualification level of sportsmen-skiers, as well as to compare sportsmen of different qualification levels. This model allows to predict the level of physical fitness and sports success of athletes.

Keywords: adaptation; hemodynamics; spectral structure of physiological parameters; statistical analysis; Dirichlet distribution.
\end{abstract}

\section{The Original Data and the Categorization of the Spectrum}

The circulatory system is an universal indicator of adaptation. In the Central hemodynamics, oscillations occur on the basis of changes in the cycle of each heartbeat [1-5]. Variability of these indicators is caused by interrelations of functioning of blood circulation and dynamic reactions of regulatory systems [6]. Heart rate oscillations change hemodynamics, modelling the pulsation of blood flow, which in comparison with the rigid rhythm increases energy consumption [7]. Spectral analysis is an important indicator for assessing the vibrancy in the blood flow system. Variability, adaptability and oscillation are wave-like processes that provide the unity of stability and instability determined by oscillatory processes [7].

A. Isaev and A. Astakhov $[8,9]$ proposed the following mechanism of variability of the flow of slow-wave oscillations of blood circulation parameters:

- ultra-low frequency oscillations (ULF, P1), including neurogenic suprasegmental levels, neurogenic mechanisms of regulation of Central and peripheral blood flow;

- very low-frequency oscillations (P2), including suprasegmentally level, humoralhormonal and transient periodic manifestations of the trigger mechanism that provides the generation of rhythmic phase contractions; 
- low-frequency oscillations of blood flow (P3) regulated by the segmental level of neuromotor support, sympathetic and parasympathetic departments of the autonomic nervous system, chemo- and baroreceptor, proprioreceptor mechanisms;

- high-frequency slow-wave oscillations (P4) providing a segmental level of blood flow regulation, and describing the contribution of parasympathetic factors explained by Autonomous, proprioceptive myogenic and neuromotor mechanisms.

The slowest oscillations (from 0 to $0.025 \mathrm{~Hz}$ ) occur due to metabolism. More frequent (from 0.025 to $0.075 \mathrm{~Hz}$ ) are associated with the frequency of hormonal activity of the blood; oscillations taking values from 0.075 to $0.15 \mathrm{~Hz}$ occur due to baroregulation; the most frequent oscillations (from 0.015 to $0.50 \mathrm{~Hz}$ ) are synchronous with breathing. All oscillations can be characterized by power, which is calculated as the square of the wave amplitude. A sharp decrease in the power of oscillations means low activity of regulation systems and vice versa [9].

The survey involved two groups of ski racers. The first group (Leaders) is formed by the highly qualified athletes in the number of seven people. The second group (General group) is formed by 10 athletes, which have slightly lower level of sports classification.

Experimental data (parameters of the cardiovascular system) reflect the level of adaptation of athletes to physical activity and were obtained using the system "MARG 10-01" ("Centaur") and subjected to spectral analysis, which is based on the technique of fast Fourier transform.

Spectral characteristics of the following parameters were studied

- BP, mmHg.st. is a mean dynamic blood pressure,

- HR is a heart rate,

- BPM is a heart rate (HR-heart rate) recorded by R-R (sec) interval I standard ECG lead,

- SV, $\mathrm{ml}$ is a percussive blood volume (calculated using Kubitschek's ECG formula and the first transthoracic rheogram derivative),

- $\mathbf{C O}, \frac{l}{\min }$ is a minute volume of blood circulation,

- EF, \% is a left ventricular ejection fraction (calculated using Tagift's ECG formula and the first transthoracic rheogram derivative),

- ATHRX, mom is an amplitude of pulsation of large vessels (aorta),

- ATOM, mom is an amplitude of pulsation of small (peripheral) vessels,

- RespX, IOM is a breathing parts of Raavan aorta,

- RespT is a Raavana chest, small vessels,

- FW, mom is a amplitude of diastolic wave of heart filling.

A sample of an experimental data on the $\mathbf{H R}$ indicator is given in Table 1.

Table 1

Experimental results of spectral analysis

\begin{tabular}{|c|c|c|c|c|c|c|c|}
\hline ID & HR & HR power & HR Fm & $H R P_{1}$ & $H R P_{2}$ & $H R P_{3}$ & $H R P_{4}$ \\
\hline 3 & 59.0 & 3.11 & 0.03 & 0.91 & 1.97 & 0.05 & 0.18 \\
\hline 6 & 57.80 & 5.60 & 0.10 & 0.80 & 1.20 & 0.70 & 3,00 \\
\hline
\end{tabular}


Here

- the leftmost column is the ID of an athlete;

- HR is the measured value of the indicator;

- Power is the total power of the spectrum of slow-wave oscillations of the indicator for 500 cardiointervals;

- Fm is the actual mid-frequency of the spectrum (the average frequency of variability of blood flow parameters);

- $P_{N}(N=1,2,3,4)$ is the reduced power of slow-wave oscillations in the previously allocated (ultra-low frequency (ULF), very low frequency (LF), low frequency (LF), high frequency $(\mathrm{HF})$ ) spectrum ranges, which can be characterized by the parameters given in Table 2 .

Table 2

\begin{tabular}{|c|c|c|c|c|}
\hline Group & $P_{1}$ & $P_{2}$ & $P_{3}$ & $P_{4}$ \\
\hline Range $(\mathrm{Hz})$ & $<0.003$ & $0.003-0.04$ & $0.04-0.15$ & $0.15-0.4$ \\
\hline
\end{tabular}

\section{Integral Rating Indicator}

In order to establish the relations between the spectral characteristics of the parameters at our disposal and the level of qualification of athletes, we develop a method of constructing an integral rating indicator (hereinafter IR) was developed, based on information about the achievements of athletes in high-ranking competitions. This information is contained in the following indicators: the athlete's place in the all-Russian database (two lists) and the so-called RUS-points ${ }^{1}$ (two lists). Fig. 1 shows the dynamics of changes in the IR for athletes who participated in the survey.

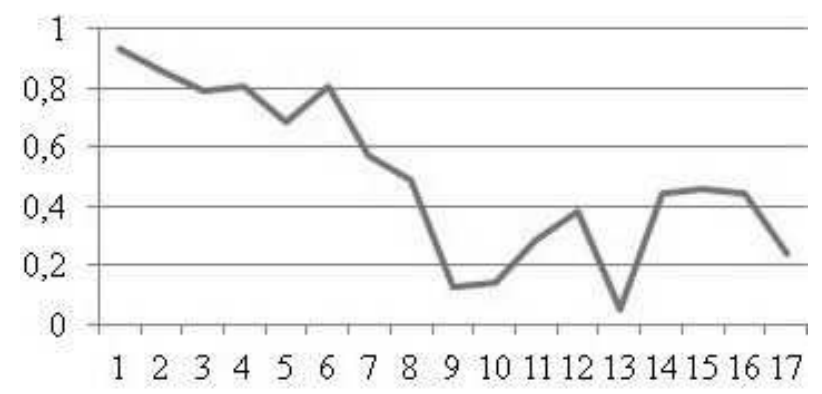

Fig. 1. The dynamics of the IR for skiers high sports qualification (1-7) and other athletes (8-17)

The calculated indicator of IR quite well accumulated information about the success and achievements of athletes contained in the studied parameters (see Table $3^{2}$ ).

\footnotetext{
${ }^{1}$ The latter were awarded points on each ski race, each time in a new way, depending on the result shown.

${ }^{2}$ Marked significant at $95 \%$ level coefficients.
} 
Table 3

Correlation table

\begin{tabular}{|c|c|c|c|c|c|}
\hline & IR & RUS point, distance & location & RUS point. sprint & location 1 \\
\hline IR & 1 & $-.924^{* *}$ & $-.915^{* *}$ & $-.939^{* *}$ & $-.951^{* *}$ \\
\hline RUS point, distance & $-.924^{* *}$ & 1 & $.982^{* *}$ & $.762^{* *}$ & $.793^{* *}$ \\
\hline location & $-.915^{* *}$ & $.982^{* *}$ & 1 & $.771^{* *}$ & $.800^{* *}$ \\
\hline RUS point. sprint & $-.939^{* *}$ & $.762^{* *}$ & $.771^{* *}$ & 1 & $.946^{* *}$ \\
\hline location & $-.951^{* *}$ & $.793^{* *}$ & $.800^{* *}$ & $.946^{* *}$ & 1 \\
\hline
\end{tabular}

An example of these data and the calculated IR is given in Table 4.

Table 4

Integral rating indicator

\begin{tabular}{|c|c|c|c|c|c|}
\hline Athlete ID & RUS point, distance & location & RUS point. sprint & location & IR \\
\hline 1 & 13.86 & 9.00 & 27.73 & 8.00 & 0.9327 \\
\hline 2 & 14.18 & 10.00 & 80.18 & 31.00 & 0.8606 \\
\hline 3 & 15.40 & 13.00 & 97.24 & 63.00 & 0.7885 \\
\hline 4 & 32.35 & 34.00 & 85.10 & 27.00 & 0.8029 \\
\hline 5 & 46.28 & 69.00 & 109.46 & 86.00 & 0.6875 \\
\hline 6 & 67.89 & 77.00 & 25.43 & 5.00 & 0.8029 \\
\hline 7 & 56.82 & 87.00 & 161.85 & 143.00 & 0.5721 \\
\hline 11 & 85.26 & 125.00 & 150.14 & 171.00 & 0.4856 \\
\hline 12 & 180.28 & 485.00 & 220.89 & 310.00 & 0.1250 \\
\hline 13 & 135.38 & 330.00 & 222.88 & 335.00 & 0.1394 \\
\hline 14 & 101.95 & 216.00 & 197.35 & 261.00 & 0.2836 \\
\hline 15 & 82.77 & 168.00 & 185.38 & 193.00 & 0.3846 \\
\hline 16 & 183.28 & 490.00 & 225.89 & 313.00 & 0.0529 \\
\hline 17 & 73.22 & 136.00 & 148.36 & 266.00 & 0.4423 \\
\hline 18 & 134.15 & 285.00 & 109.74 & 85.00 & 0.4567 \\
\hline 19 & 80.20 & 130.00 & 166.65 & 206.00 & 0.4423 \\
\hline 20 & 146.48 & 373.00 & 183.35 & 260.00 & 0.2404 \\
\hline
\end{tabular}

\section{Cluster Analysis}

The relationship between IR and the physiological indicators of athletes available to researchers is of particular interest. Clustering of the data used in the analysis [10] allows all athletes participating in the survey (17 people) to be divided into four groups (clusters) corresponding to their competitive success in accordance with the individual value of the IR assigned to each athlete. The first group includes all the athletes of high qualification. Their IR is higher than 0.49 . The second group includes the athletes with IR in the range from 0.33 to 0.49 . The third group includes the athletes with IR in the range from 0.2 to 0.33. Finally, the fourth group includes the athletes with IR lower than 0.20.

As shown by the preliminary statistical analysis, the experimental data available to us did not demonstrate significant and sufficiently stable correlation-regression dependencies between the variables included in the analysis and the IR (see Table. $5^{3}$ ).

\footnotetext{
${ }^{3}$ Marked significant at $95 \%$ level coefficients
} 
Low levels of correlation do not allow to predict sports achievements reliably enough relying on the variables chosen for the analysis. However, it turns out that the affiliation

Table 5

Pearson correlations between IR and ones included in the analysis indicators

\begin{tabular}{|c|c|c|c|c|c|c|c|c|c|}
\hline & HR & SV & CO & EF & ATHRX & ATOE & RespX & RespT & FW \\
\hline Ind. success & .216 & $-.556^{*}$ & $-.487^{*}$ & -.159 & $-.500^{*}$ & $.492^{*}$ & -.267 & $-.573^{*}$ & -.319 \\
\hline significans & .404 & .021 & .047 & .543 & .041 & .045 & .301 & .016 & .212 \\
\hline
\end{tabular}

of an individual to one of the above clusters of sports success is reliably predicted by the totality of the analyzed parameters.

\section{Discriminant Analysis}

In statistics discriminant analysis refers to several related statistical procedures. These procedures are conventionally divided into procedures for interpreting intergroup differences, which are actually called discrimination methods, and procedures for classifying observations into groups using one or more classifying functions depending on the parameters observed in the experiment. Interpretation procedures answer the question on the possibility to distinguish one group from another using a given set of variables, as well as on the quality and informativeness of this distinction. Classification methods are associated with obtaining one or more functions that allow to refer this object to one of the groups. These functions are called discriminant and depend on the values of the indicators in such a way that it is possible to attribute each object to one of the groups. In the considered situation, the intergroup differences are differences in the level of sports success of the surveyed athletes (see Table $6^{4}$ ).

Table 6

Discrimination groups

\begin{tabular}{|c|c|c|}
\hline IR & Claster & Characteristics of a cluster \\
\hline $0.50-1,0$ & I & Athletes of extra qualification \\
\hline $0.33-0.5$ & II & Athletes of high qualification \\
\hline $0.20-0.33$ & III & Athletes of average qualification \\
\hline $0.00-0.20$ & IV & Athletes below average qualification \\
\hline
\end{tabular}

The considered problem is the classification of the observations at our disposal by the groups given in Table 6 depending on the values of the analyzed indicators. In other words, how available physiological indicators reflect belonging to one of the selected groups.

Table 7 gives the main statistical characteristics of these indicators, i.e. group averages.

The distribution of statistical indicators by groups and indicators shows the following trend. The groups were dominated by indicators that ensure success in the following ranking arrangement: RespX, RespT, BP, SV, EF in the 1st group; RespX, RespT, BP, $\mathrm{SV}, \mathrm{EF}, \mathrm{HR}$, ATOE in the 2nd group; RespX, RespT, ATOE, BP, SV, HR, EF in the 3rd group; RespX, RespT, ATOE, BP, SV, EF, HR, ATHRX in the 4th group. It can

\footnotetext{
${ }^{4}$ The list of qualifications is built on the basis of the success of the surveyed athletes and is conditional, not absolute, in nature.
} 
Table 7

Group average

\begin{tabular}{|c|c|c|c|c|c|}
\hline Group & I & II & III & IV & Total \\
\hline BP & 80.9 & 84.5 & 85.5 & 85.0 & 83.0 \\
\hline HR & 61.6 & 57.0 & 60.5 & 57.3 & 59.6 \\
\hline SV & 67.0 & 71.3 & 65.0 & 97.3 & 73.1 \\
\hline CO & 3.96 & 3.75 & 4.0 & 5.67 & 4.22 \\
\hline EF & 60.4 & 59.8 & 57.0 & 62.7 & 60.2 \\
\hline ATHRX & 29.7 & 11.3 & 9.5 & 126.0 & 40.0 \\
\hline ATOE & 121. & 52.0 & 121. & 49.3 & 92.2 \\
\hline RespX & 204. & 202. & 203. & 214. & 205. \\
\hline RespT & 167. & 189. & 181. & 189. & 177. \\
\hline FW & 1.58 & 2.5 & 3.0 & 2.0 & 2.04 \\
\hline
\end{tabular}

be assumed that the skiers-racers of different levels of class in ensuring sports success dominated the respiratory waves of large, medium and small vessels. Small circle of blood circulation, average dynamic pressure, shock volume, heart rate, myocardial contractility, amplitude of peripheral vascular rheowaves (1-2 groups) are actively involved. In the 3rd group, along with respiratory waves, the amplitude of pulsations of small vessels was recorded. In the 4th group, aortic rheowave amplitude indices were added. Venous return consistently increased in the 3rd group and decreased in the 4th group, but was higher than in the 1st. It can also be assumed that the main causes of vegetative, humoral-hormonal interaction were expressed in all skiers-racers in the amplitudes of respiratory waves of different localization, due to high-frequency components (HF), which are the criteria for modulation of the vagus nerve (bradycardia). The rhythm related to vasomotor waves conditioned as the ratio of low-frequency and high-frequency components (LF/HF) with the presence of mean dynamic pressure and heart rate variability can be attributed to the balance of parasympathetic and sympathetic regulation.

Table 8

Coefficients of the classification functions

\begin{tabular}{|c|c|c|c|c|}
\hline & I & II & III & IV \\
\hline BP & -3.25 & -2.79 & -3.3 & -2.63 \\
\hline HR & 53.9 & 53.4 & 54.9 & 51.0 \\
\hline SV & 42.8 & 42.5 & 43.6 & 40.4 \\
\hline CO & -664. & -659. & -681. & -631. \\
\hline EF & 36.9 & 36.5 & 36.5 & 36.4 \\
\hline ATHRX & -3.61 & -3.61 & -3.59 & -3.37 \\
\hline ATOE & 11.3 & 11.1 & 11.6 & 10.8 \\
\hline RespX & 15.5 & 15.4 & 15.9 & 14.9 \\
\hline RespT & 20.8 & 20.5 & 21.4 & 20.2 \\
hline FW & 158. & 158. & 164. & 151. \\
\hline CONSTANT & $-6.84 \mathrm{E} 3$ & $-6.73 \mathrm{E} 3$ & $-7.09 \mathrm{E} 3$ & $-6.38 \mathrm{E} 3$ \\
\hline
\end{tabular}

Table 8 gives the coefficients of classifying functions. These functions are used to classify existing observations and to predict the membership of new measurements for each group. 
For example, the function

$$
\begin{gathered}
F_{1}=-3.25 B P+53.9 H R+42.8 S V-664.0 C O+36.9 E F- \\
-3.61 A T H R X+11.3 A T O E+15.5 \operatorname{Resp} X+20.8 \operatorname{Resp} T+158 F W-6.84 \cdot 10^{3}
\end{gathered}
$$

used to identify belonging to the first group. Similarly, the second, third, and fourth columns make it possible to construct such functions for the second, third, and fourth groups. The individual belongs to the group for which the classifying function takes the greatest value.

The results of the classification are shown in Table 9 .

As follows from this table, the constructed classification functions correctly identify about $95 \%(94,12 \%)$ of the available measurements. The classification error for one of the four representatives of the second group ( $\mathrm{ID}=15)$ is most likely caused by the athlete being in the developmental adaptation phase. For the first group of athletes (leaders), the level of success coincided $100 \%$ with the functional state, which indicates that the athletes are in the phase of sustainable adaptation.

\section{Table 9}

The classification table

\begin{tabular}{|c||c||c|c|c|c|}
\hline \multicolumn{1}{|c||}{} & \multicolumn{1}{c||}{ Actual belonging (\%) } & \multicolumn{4}{c|}{ Classification result (\%) } \\
\hline I & 100 & 100 & 0.0 & 0.0 & 0.0 \\
\hline II & 100 & 25 & 75 & 0.0 & 0.0 \\
\hline III & 100 & 0.0 & 0.0 & 100 & 0.0 \\
\hline IV & 100 & 0.0 & 0.0 & 0.0 & 0.0 \\
\hline & & I & II & III & IV \\
\hline
\end{tabular}

An important circumstance is that the classification functions allow to predict the success of the available physiological data. Discriminant functions play an important role in interpreting the results of discriminant analysis. The functions are arranged in such a way that the first of the functions is designed to distinguish as effectively as possible the belonging of the examined individual to a particular (I-IV) selected group by the values of the indicators included in the analysis, the second function complements the discrimination implemented by the first function, the third function complements the first and second functions.

Table 10

The effectiveness of discrimination

\begin{tabular}{|c|c|c|c|}
\hline Function & \% explained variance & cumulative $\%$ & Canonical correlation \\
\hline 1 & 72.6 & 72.6 & .942 \\
\hline 2 & 18.0 & 90.6 & .813 \\
\hline 3 & 9.4 & 100.0 & .711 \\
\hline
\end{tabular}

The efficiency of discrimination is described by the proportion of explained variability realized by the discriminant function (see Table 10). Of particular interest are the normalized coefficients of discriminant functions, demonstrating the degree of influence on the quality of discrimination of one or another of the analyzed variables (see Table 11, left part). 
Table 11

Normalized coefficients (left) and Structural matrix (right)

\begin{tabular}{|c||c|c|c|}
\hline \multicolumn{1}{|c||}{ Indicator } & \multicolumn{3}{c|}{ Functions } \\
\hline & 1 & 2 & 3 \\
\hline BP & -.518 & .407 & -.193 \\
\hline HR & 5.134 & 1.561 & -1.848 \\
SV & 7.482 & 2.437 & -3.551 \\
\hline CO & -6.673 & -2.624 & .749 \\
\hline EF & .150 & -.363 & -.222 \\
\hline ATHRX & -1.758 & -.263 & 2.980 \\
\hline ATOE & 2.941 & .065 & 1.316 \\
\hline RespX & 1.405 & .728 & .028 \\
\hline RespT & 1.551 & .483 & 1.714 \\
\hline FW & .973 & .931 & .149 \\
\hline \multicolumn{2}{|c|}{}
\end{tabular}

\begin{tabular}{|c||c|c|c|}
\hline \multicolumn{1}{|c||}{ Indicator } & \multicolumn{3}{c|}{ Functions } \\
\hline & 1 & 2 & 3 \\
\hline SV & $-.227^{*}$ & -.028 & .214 \\
\hline FW & .007 & $.557^{*}$ & .207 \\
\hline RespT & -.241 & $.538^{*}$ & .068 \\
\hline ATOE & .401 & $-.474^{*}$ & .274 \\
\hline EF & -.215 & $-.296^{*}$ & -.087 \\
\hline BP & -.074 & $.264^{*}$ & .164 \\
\hline HR & .060 & $-.101^{*}$ & .033 \\
\hline CO & -.193 & -.103 & $.361^{*}$ \\
\hline ATHRX & -.244 & -.202 & $.352^{*}$ \\
\hline RespX & -.102 & -.084 & $.172^{*}$ \\
\hline
\end{tabular}

Larger absolute coefficients indicate a greater influence of the corresponding variable on the values of the discriminant function. The structural matrix of the discriminant analysis (see Table 11, right part ${ }^{5}$ ) gives the values of intragroup correlations between discriminant variables and normalized canonical discriminant functions. Systemic regulation of the organism of skiers-racers is carried out in rating terms in the following order (according to the magnitude of the presented coefficients of discriminant functions): SV-heart rateATOE-RespT-RespX.

The physiological mechanisms of such distributions are quite understandable, since they determine the oxygen transport function of the body, including skeletal muscles, myocardium and respiratory muscles.

\section{Simulation Model of Spectrum. The Dirichlet Distribution}

The basis for the quantitative analysis of the level of adaptation of athletes to physical activity can serve as a simulation model of the spectral structure of the studied physiological parameters of athletes. It also makes it possible to predict the level of physical fitness and success of athletes.

Let $\xi=\left\{P_{1}, P_{2}, P_{3}, P_{4}\right\}$ be a random vector whose components are the reduced power of slow-wave oscillations, $P_{1}+P_{2}+P_{3}+P_{4}=1$. It is said $[6,11]$ that a vector $\xi$ has a Dirichlet distribution with parameters $\Lambda=\left\{\lambda_{1}, \lambda_{2}, \lambda_{3}, \lambda_{4}\right\}$ if the distribution density of this vector is given by the expression

$$
f_{\xi}(x ; \Lambda)=\frac{\Gamma\left(\lambda_{1}+\lambda_{2}+\lambda_{3}+\lambda_{4}\right)}{\Gamma\left(\lambda_{1}\right) \Gamma\left(\lambda_{2}\right) \Gamma\left(\lambda_{3}\right) \Gamma\left(\lambda_{4}\right)} x_{1}^{\lambda_{1}-1} x_{2}^{\lambda_{2}-1} x_{3}^{\lambda_{3}-1} x_{4}^{\lambda_{4}-1}, \quad \lambda_{i} \geq 0 .
$$

Here $\Gamma(x)$ is the Euler's gamma function.

It turned out that the spectral structure of physiological parameters of athletes-skiers can be adequately described by this distribution. In this case, each individual indicator is characterized by its own Dirichlet distribution parameters, which are to be determined by the available experimental measurements.

\footnotetext{
${ }^{5}$ Significant correlations are marked with an asterisk.
} 
If it is known beforehand that the experimental data are homogeneous (in the sense that they are chosen from the Dirichlet distribution with the same parameters), then the parameters can be estimated using one of the standard methods of statistical estimation, for example, the method of moments.

In our situation, the system of the method of moments is always uniquely solvable and its solution is the statistics given by the formula:

$$
\hat{\lambda}_{i}=\overline{x_{i}} \cdot\left(\frac{\overline{x_{k}}\left(1-\overline{x_{k}}\right)}{S_{k}^{2}}-1\right) .
$$

In formula (2), the index $i$ is fixed (one of the possible 1,2,3,4), and the index $k$ runs through all values of $1,2,3,4$.

An example of the parameter estimation for BP is given in Table 12 (left part).

Table 12

Estimated (left) and reconfigured (right) parameters for BP

\begin{tabular}{|c||c|c|c|c||c||c|c|c|c|}
\hline & I & II & III & IV & & I & II & III & IV \\
\hline$\lambda_{1}$ & 2.2637 & 0.6646 & 0.5159 & 0.3802 \\
\hline$\lambda_{2}$ & 7.4917 & 2.9134 & 1.8860 & 0.9703 \\
\hline$\lambda_{3}$ & 8.2104 & 5.7152 & 2.5112 & 1.1774 \\
\hline$\lambda_{4}$ & 0.0000 & 0.0111 & 0.3378 & 0.0944 \\
\hline$\hat{\lambda}_{2}$ & 2.0910 & 0.5755 & 0.5535 & 0.4141 \\
\hline$\hat{\lambda}_{3}$ & 7.3406 & 5.4886 & 2.1950 & 1.0958 \\
\hline$\hat{\lambda}_{4}$ & 0.0000 & 0.0013 & 0.2591 & 0.0745 \\
\hline
\end{tabular}

Using of formulas (2) to estimate the Dirichlet distribution parameters from the available real spectral data is complicated by their small volume. This leads to low estimation accuracy and, as a consequence, to an incorrect description of the distributions of the studied parameters.

In order to increase the sample size for estimating the Dirichlet distribution parameters, a computational experiment was conducted. The well known $[11,12]$ relationship between the Dirichlet distribution and the gamma distribution was used to emulate implementations of the Dirichlet distribution. The emulated data was used to refine the values of the parameters sought. The results of the reconfiguration of the parameters for BP are given in table 12 (right part).

The final step of the computational experiment was the usual test of the hypothesis about the distribution of experimental measurements.

\section{Conclusion}

We develop the technique of statistical analysis of morphometric, biochemical, hematological and other indicators of the functional state of athletes. Also we offer the rating analysis of success of athletes in competitions of various ranks and construct integral rating indicator of success. We establish the relationship between the spectral characteristics of individual indicators and the level of qualification of sportsmen. We construct a stochastic model of spectral parameters of morphofunctional indices of sportsmen, which allows to establish a connection between Dirichlet distributions parameters, morphofunctional indices and qualification level of sportsmen-skiers, as well as to compare sportsmen of different qualification levels. 


\section{References}

1. Bauer P., Kraushaar L., Most A., Keller T. Impact of Vascular Function on Maximum Power Output in Elite Handball Athletes. Research Quarterly for Exercise and Sport, 2019, vol. 90, no. 4, pp. 600-608.

2. Bernstein N. A. [Selected Works on Biomechanics and Cybernetics]. Moscow, 2001. (in Russian)

3. Degtyarev V. A. The Defining Role of Aortal Rigidity in Blood Circulation Function Remodeling. Kazan Medical School Diary, 2015, no. 2 (8), pp. 6-10. (in Russian)

4. Gavrilova E. A., Sherenkov A. O., Davydov V. V. Modern Representations about Adaptation of the Device of Blood Circulation to the Physical Loadings. I.P. Pavlov Russian Medical Biological Herald, 2007, vol. 8, no. 4, pp. 133-140. (in Russian)

5. Samoilenko A. V. Venous Return in Systemic Haemodynamics. Russian Journal of Physiology, 2011, issue 97, no. 1, pp. 3-23. (in Russian)

6. Yakhontov S. V., Kulemzin A. V. The Interaction of Regulatory Mechanism During the Modelling of Transitive Processes. Tomsk State Pedagogical University Bulletin, 2009, issue 3 (81), pp. 12-15. (in Russian)

7. Galichy V. A. Biorhythmological Aspects of Assessment and Forecasting of the State of the Organism in the Practice of Space Medicine. Abstract of DSc Thesis. Moscow, 1996. (in Russian)

8. Astakhov A. A. [Physiological Fundamentals of Bioimpedance Monitoring of Hemodynamics with the Kentavr System: A Manual for Anesthesiologists], Chelyabinsk, 1996. (in Russian)

9. Bakhareva A. S. Features of the Functional State of the Autonomic Nervous System and Neuromuscular Apparatus of Skiers-Racers in the Mesocycle. Proceedings of the 66th SUSU Scientific Conference. Chelyabinsk, Publishing center of SUSU, 2014, pp. 74-81. (in Russian)

10. Isaev A. P., Ehrlich V. V. [Fundamental and Applied Aspects of Adaptability, Reactivity and Regulation of Athletes in the System of Sports Training (Nutrition, Digestion, Recovery and Energy Supply)]. Chelyabinsk, Publishing center of SUSU, 2017. (in Russian)

11. DeGroot M. Optimal Statistical Decisions. New York, McGraw-Hill Book Company, 1970.

12. Wilks S. Mathematical Statistics. N.Y., London, John Wiley \& Sons, 1962.

Vladimir I. Zalyapin, PhD (Math), Professor, Department of Mathematical Analysis and Methods of Teaching Mathematics, South Ural State University (Chelyabinsk, Russian Federation), zaliapinvi@susu.ru.

Alexander P. Isaev, DSc (Biology), Professor, Department of Theory and Methodology of Physical Culture and Sports, South Ural State University (Chelyabinsk, Russian Federation),isaevap@susu.ru. 
Anatasiya S. Bakhareva, PhD (Biology), Associate Professor, Department of Sports Perfection, South Ural State University (Chelyabinsk, Russian Federation), bakharevaas@susu.ru.

Albina S. Aminova, Graduate Student, Department of Sports Perfection, South Ural State University (Chelyabinsk, Russian Federation), aminovaas@susu.ru.

Received November 25, 2019

УДК 519.25, 612.1

DOI: $10.14529 /$ jcem190405

\title{
МОДЕЛИРОВАНИЕ СПЕКТРАЛЬНЫХ ХАРАКТЕРИСТИК СИСТЕМЫ КРОВООБРАЩЕНИЯ СПОРТСМЕНОВ-ЛЫЖНИКОВ
}

\author{
В. И. Заляпин, А. П. Исаев, А. С. Бахарева, А. С. Аминова
}

\begin{abstract}
Система кровообращения является универсальным индикатором адаптации. Колебания звеньев центральной гемодинамики происходят на базе изменений в цикле каждого удара сердца. Вариативность этих показателей обусловлена взаимоотношениями функционирования кровообращения и динамических реакций регуляторных систем. Колебания ритма сердца изменяют гемодинамику, моделируя пульсацию кровотока, что по сравнению с ригидным ритмом увеличивает энергозатраты. Основой для количественного анализа уровня адаптации спортсменов к физическим нагрузкам послужила имитационная модель спектральной структуры исследуемых физиологических показателей спортсменов. Оказывается, спектральная структура физиологических показателей спортсменов достаточно адекватно может быть описана распределением Дирихле. При этом каждый отдельный показатель характеризуются собственными параметрами этого распределения, которые определяются по имеющимся экспериментальным данным. Построена стохастическая модель спектральных параметров морфофункциональных показателей спортсменов, которая позволяет установить связь между параметрами распределения Дирихле, морфофункциональными показателями и квалификационным уровнем спортсменов-лыжников, а также провести сравнение спортсменов различных квалификационных уровней. Эта модель дает возможность прогнозировать уровень физической подготовленности и спортивной успешности спортсменов.
\end{abstract}

Ключевые слова: адаптация; спектральная структура физиологических параметров; статистический анализ; распределение Дирихле.

\section{Литература}

1. Bauer, P. Impact of Vascular Function on Maximum Power Output in Elite Handball Athletes / P. Bauer, L. Kraushaar, A. Most, T. Keller // Research Quarterly for Exercise and Sport. - 2019. - V. 90, № 4. - P. 600-608.

2. Бернштейн, Н. А. Избранные труды по биомеханике и кибернетике / Н. А. Бернштейн. - М.: СпортАкадемПресс, 2001.

3. Дегтярев, В. А. Определяющая роль увеличения ригидности аорты при перестройке функции кровообращения / В. А. Дегтярев // Дневник Казанской медицинской школы.- 2015. - № 2 (8). - С. 6-10. 
4. Гаврилова, Е. А. Современные представления об адаптации аппарата кровообращения к физическим нагрузкам / Е. А. Гаврилова, А. О. Шеренков, В. В. Давыдов // Российский медико-биологический вестник им. акад. И.П. Павлова. 2007. - № 4. - C. 133-140.

5. Самойленко, А. В. Венозный возврат в системе гемодинамики / А. В. Самойленко // Российский физиологический журнал им. И. М. Сеченова. - 2011. - Т. 97, № $1 .-$ C. 3-23.

6. Яхонтов, С. В. Взаимодействие регуляторных механизмов при моделировании переходных процессов / С. В. Яхонтов, А. В. Кулемзин // Вестник Томского государственного педагогического университета. - 2009. - Вып. 3 (81), - С. 12-15.

7. Галичий, В. А. Биоритмологические аспекты оценки и прогнозирования состояния организма в практике космической медицины: автореф. дисс. ... д-ра мед. наук / В. А. Галичий. - Москва, 1996.

8. Астахов, А. А. Физиологические основы биоимпедансного мониторинга гемодинамики в анастезиологии (с помощью системы KEHTABP): учеб. пособие для врачей и анестезиологов / А. А. Астахов. - Челябинск: Микролюкс, 1996.

9. Бахарева, А. С. Особенности функционального состояния вегетативной нервной системы и нервно-мышечного аппарата лыжников-гонщиков в мезоцикле / А. С. Бахарева // Наука ЮУрГУ: Материалы 66-й научной конференции. - Челябинск: Издательский центр ЮУрГУ, 2014. - С. 74-81.

10. Исаев, А. П. Фундаментальные и прикладные аспекты адаптоспособности, реактивности и регуляции организма спортсменов в системе спортивной подготовки (питание, пищеварение, восстановление и энергообеспечение) / А. П. Исаева, В. В. Эрлиха. - Челябинск: Издательский центр ЮУрГУ, 2017.

11. Де Гроот, М.. Оптимальные статистические решения / М. Де Гроот. - М.: Мир, 1974.

12. Уилкс, С. Математическая статистика / С. Уилкс. - М.: Наука, 1967.

Заляпин Владимир Ильич, кандидат физико-математических наук, профессор, кафедра математического анализа и методики преподавания математики, ЮжноУральский государственный университет (г. Челябинск, Российская Федерация), zaliapinvi@susu.ru.

Исаев Александр Петрович, доктор биологических наук, профессор, кафедра теории и методики физической культуры и спорта, Южно-Уральский государственный университет (г. Челябинск, Российская Федераиия), isaеvap@susu.ru.

Бахарева Анастасия Сергеевна, кандидат биологических наук, дочент, кафедра спортивного совершенствования, Южно-Уральский государственный университет (2. Челябинск, Российская Федерачия), bakharevaаs@susu.ru.

Аминова Альбина Сибагатулловна, аспирантка, кафедра спортивного совершенствования, Южно-Уральский государственный университет (г. Челябинск, Российская Федерачия), aminovaаs@susu.ru

Поступила в редакцию 25 ноября 2019 г. 